\title{
LOOSENING OF THE CEMENTED ACETABULAR CUP IN TOTAL HIP REPLACEMENT
}

\author{
G. B. J. Andersson, M. A. R. Freeman and S. A. V. Swanson, London, England
}

The use of cold-curing acrylic "cement" as a method of fixation for total hip replacements is now widespread. The improved stress distribution from prosthesis to bone is a well established fact (Charnley and Kettlewell 1965, Charnley 1970a) and, with better fixation, results in hip surgery have become more reliable. There seem to be two major reasons

TABLE I

REPORTED INCIDENCES OF LOOSENING

excluding cases of loosening accompanied by infection or following trauma

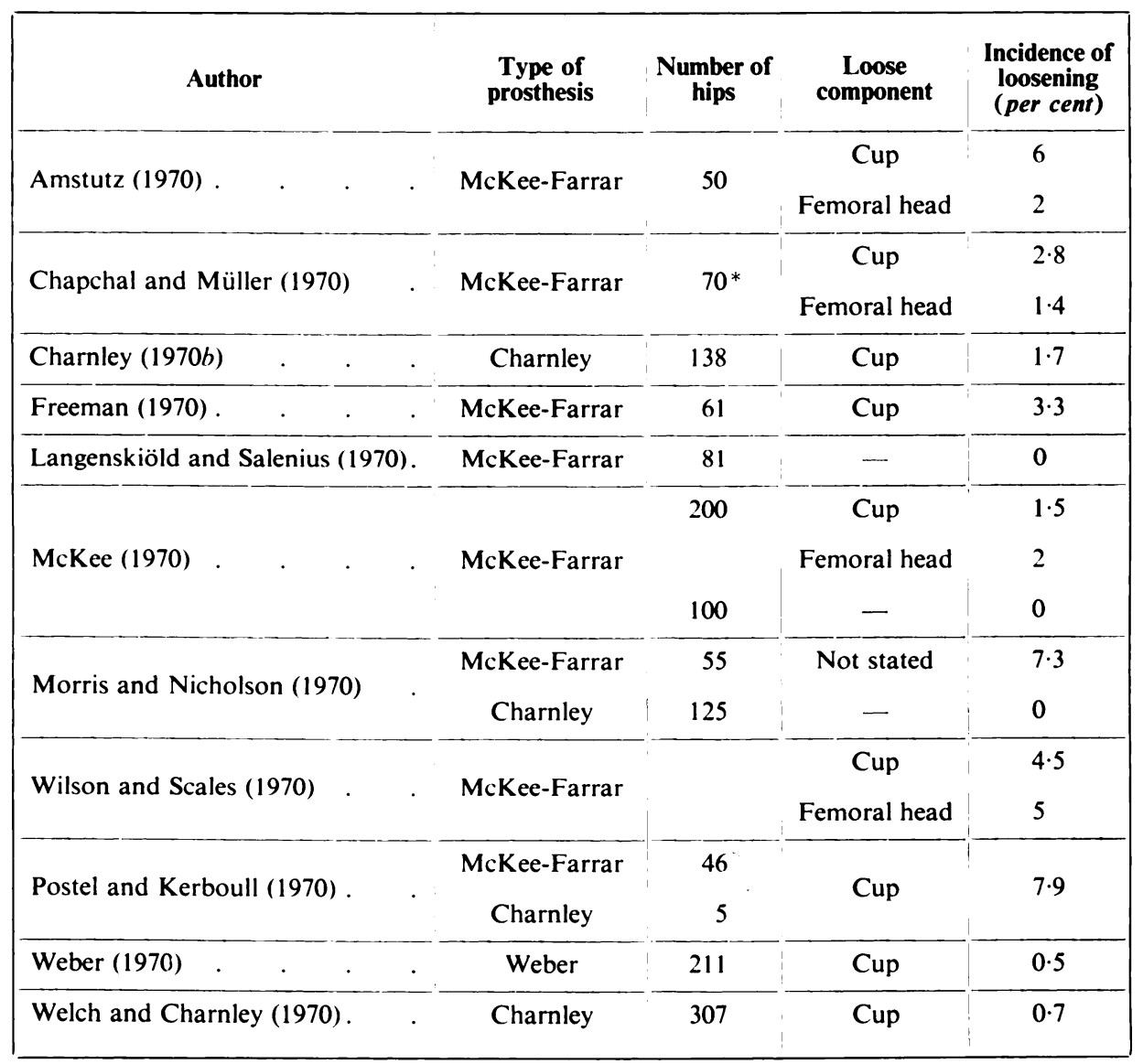

* This is the number of patients, not of hips.

for unsatisfactory results: infection and loosening of the components. This paper is concerned with loosening of the acetabular component in the absence of infection.

Loosening of one or both components has been reported many times (Table I). The time of observation has, however, been short and therefore the results listed in Table I must 
be considered as preliminary. As time goes by, the incidence of late loosening may increase, but on the other hand it may be expected that operative technique and the method of using cement will improve.

A priori, the possible reasons for loosening include bone resorption, defective technique of implantation, and defective materials. While earlier work in this field has mainly been concerned with the femoral component (Charnley and Kettlewell 1965, Wilson and Scales 1970), this paper examines the strength of the bone-prosthesis bond in the acetabulum at the time of implantation and relates the strength of the bond to the loads applied by forces acting on the prosthetic acetabulum in life. It does not deal directly with changes that may occur in the bone or in the prosthetic materials with time in the body.

\section{THE FORCES AND MOMENTS ACTING ON THE ACETABULUM IN LIFE}

When the trunk is vertical, these forces can be considered to comprise a resultant compressive force which acts in a direction inclined medially at not more than about 15 degrees from the vertical, and a friction moment which may be resolved into three components acting about three mutually perpendicular axes.

The magnitude of the resultant compressive force has been measured by Rydell (1966) and by Paul and co-workers (Paul 1967; Hughes, Paul and Kenedi 1970). The greatest value quoted by Rydell was 4.33 times body weight, this being measured in a middle-aged man who had undergone prosthetic replacement of a femoral head. The highest value quoted by Hughes and colleagues was about eight times body weight, but more typical values were about four to five times body weight for men and twice body weight for women. These results were obtained mostly in young adults.

The friction moments vary with the magnitude of the resultant load, the prosthesis geometry and the coefficient of friction between the two components. The frictional moments which act in different total hip replacements have been measured independently by Wilson and Scales (1970) and by Freeman and Swanson (unpublished material), and are summarised in Table II. It can be seen that the results recorded for a metal to metal prosthesis are different from those which relate to a metal to high density polyethylene prosthesis and that there is

TABLE II

Frictional Moments Measured in Charnley and McKee-Farrar Prostheses

\begin{tabular}{|c|c|c|c|c|c|c|c|}
\hline \multirow[b]{2}{*}{$\begin{array}{c}\text { Type of } \\
\text { prosthesis }\end{array}$} & \multirow[b]{2}{*}{$\begin{array}{l}\text { Material } \\
\text { of head }\end{array}$} & \multirow[b]{2}{*}{$\begin{array}{l}\text { Material } \\
\text { of cup }\end{array}$} & \multirow{2}{*}{$\begin{array}{l}\text { Diameter } \\
\text { of head } \\
\text { (milli- } \\
\text { metres) }\end{array}$} & \multirow[b]{2}{*}{$\begin{array}{l}\text { Source of } \\
\text { results }\end{array}$} & \multirow[b]{2}{*}{ Lubricant } & \multicolumn{2}{|c|}{$\begin{array}{l}\text { Frictional moment in Newton-metres } \\
\text { (poundsforce-inches) under }\end{array}$} \\
\hline & & & & & & $\begin{array}{c}\text { Constant load of } \\
890 \text { Newtons } \\
\text { (200 poundsforce) }\end{array}$ & $\begin{array}{c}\text { Load varying from } \\
0 \text { to } 890 \text { Newtons } \\
(0 \text { to } 200 \\
\text { poundsforce })\end{array}$ \\
\hline \multirow{3}{*}{ Charnley } & \multirow{3}{*}{$\begin{array}{l}\text { Stainless } \\
\text { steel }\end{array}$} & \multirow{3}{*}{$\begin{array}{l}\text { High } \\
\text { density } \\
\text { poly- } \\
\text { ethylene }\end{array}$} & \multirow{3}{*}{23} & \multirow{2}{*}{$\begin{array}{l}\text { Freeman and } \\
\text { Swanson }\end{array}$} & $\begin{array}{l}\text { Ringer's } \\
\text { solution. }\end{array}$ & $0 \cdot 4-1 \cdot 2(4-11)$ & - \\
\hline & & & & & Synovial fluid. & $0.47 \quad(4 \cdot 2)$ & - \\
\hline & & & & $\begin{array}{l}\text { Wilson and } \\
\text { Scales }\end{array}$ & Bovine serum & $0.90(8)$ & $\begin{array}{r}\text { Ohours : } 1 \cdot 1(10) \\
500 \text { hours : } 0.67(6)\end{array}$ \\
\hline \multirow{4}{*}{$\begin{array}{l}\text { McKee- } \\
\text { Farrar }\end{array}$} & \multirow{4}{*}{$\begin{array}{l}\text { Cobalt- } \\
\text { chromium }\end{array}$} & \multirow{4}{*}{$\begin{array}{l}\text { Cobalt- } \\
\text { chromium }\end{array}$} & \multirow{3}{*}{41} & \multirow{2}{*}{$\begin{array}{l}\text { Freeman and } \\
\text { Swanson }\end{array}$} & $\begin{array}{l}\text { Ringer's } \\
\text { solution. }\end{array}$ & $17 \cdot 4(154)$ & $8 \cdot 5(75)$ \\
\hline & & & & & $\begin{array}{l}\text { Bone fat. } \\
\text { Synovial fluid }\end{array}$ & $\begin{array}{ll}2 \cdot 3 & (20) \\
9 \cdot 8 & (88)\end{array}$ & $\begin{array}{l}1.7(15) \\
7.9(70)\end{array}$ \\
\hline & & & & $\begin{array}{l}\text { Wilson and } \\
\text { Scales }\end{array}$ & Bovine serum & $4 \cdot 5 \quad(40)$ & $\begin{array}{r}0 \text { hours : } 4 \cdot 5(40) \\
500 \text { hours : } 3 \cdot 1(27)\end{array}$ \\
\hline & & & 35 & $\begin{array}{l}\text { Freeman and } \\
\text { Swanson }\end{array}$ & Synovial fluid & $2 \cdot 7-4 \cdot 4(24-39)$ & - \\
\hline
\end{tabular}

VOL. 54 B, NO. 4, NOVEMBER 1972 
some divergence between the several values obtained for each of the two types. The difference between the two types of prosthesis would be expected, because both the materials and the radii of the contact surfaces were different. The greatest recorded friction moment with serurn as the lubricant was that of 10.4 Newton-metres (92 poundsforce-inches) for a resultant compressive load of 801 Newtons (180 poundsforce) measured by Wilson and Scales in a McKee-Farrar prosthesis which had been removed because of loosening.

\section{STRENGTH OF THE BONE-PROSTHESIS BOND IN THE LABORATORY}

Materials and methods - Normal adult human cadaveric acetabula together with the surrounding bony pelves were taken at necropsy. The specimens were stored before the experiment at -20 degrees Celsius in sealed polythene bags. They were then prepared in one or more of the

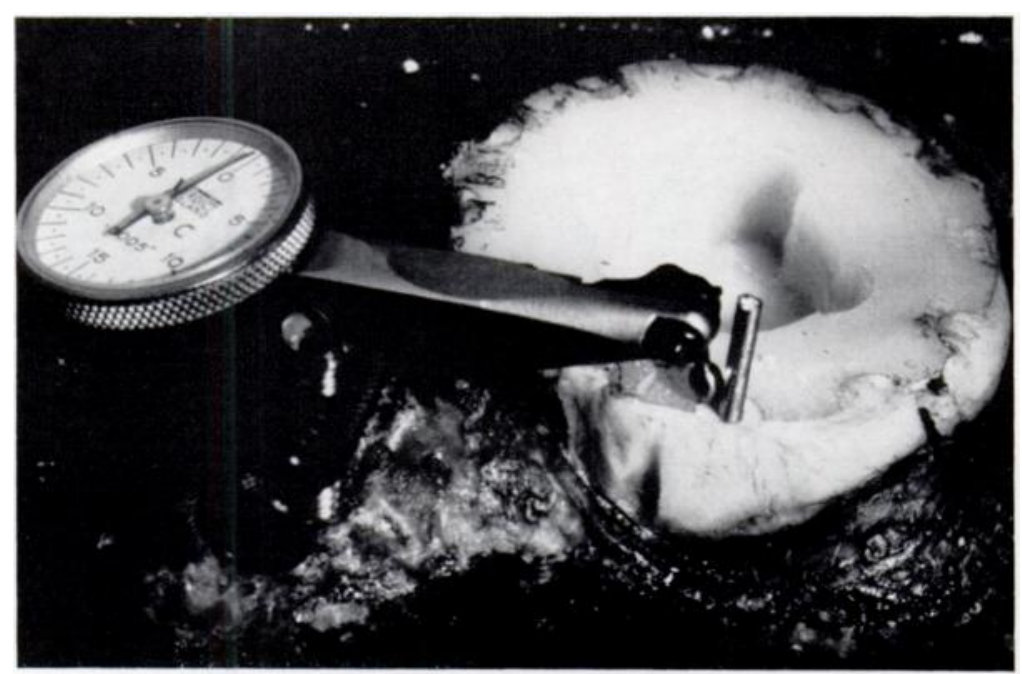

Fig. 1

A Charnley acetabular cup, modified for torsional loading, implanted in a cadaveric pelvis with the dial gauge arranged to measure tangential movement occurring between the cement and the bone.

following ways: 1) the acetabulum was left intact, 2) the cartilage was removed with a Charnley reamer or with a gouge, 3 ) the tissue in the acetabular fossa was left intact, 4) in others the fossa was carefully cleaned, or 5 ) one or three holes were drilled with a Charnley drill 0.5 inch (12.7 millimetres) in diameter. The condition of each acetabulum is listed in Tables IV, V and VI. CMW cement was prepared in the recommended proportions, barium sulphate being added. Charnley and McKee-Farrar acetabular cups were cemented into the prepared acetabula by the appropriate surgical technique and at the correct angle. All prosthetic cups were completely contained in the bony acetabulum. The specimens were then potted, using epoxy resin, in a simple torsional apparatus.

This apparatus was so arranged that a twisting moment could be applied to the prosthetic acetabular cup while the bony acetabulum was held. A dial gauge, mounted as shown in Figure 1, enabled the tangential movement between the cement and the bone to be measured. The smallest measurable movement corresponded to a rotation of about 0.03 degree.

The first test consisted in applying a constant twisting moment of 6.8 Newton-metres (60 poundsforce-inches) and recording any tangential movement, which was taken to indicate initial looseness of the fixation. 
Then each specimen was mounted, as shown in Figure 2, in a Tensometer Type E Material Testing Machine, in which a constant compressive load of up to 3,920 Newtons (880 poundsforce) was applied and maintained while the specimen was subjected to an increasing turning moment until failure occurred. Failure of the fixation was defined as an angular displacement of 20 degrees or a sudden increase in the rotation accompanied by little or no

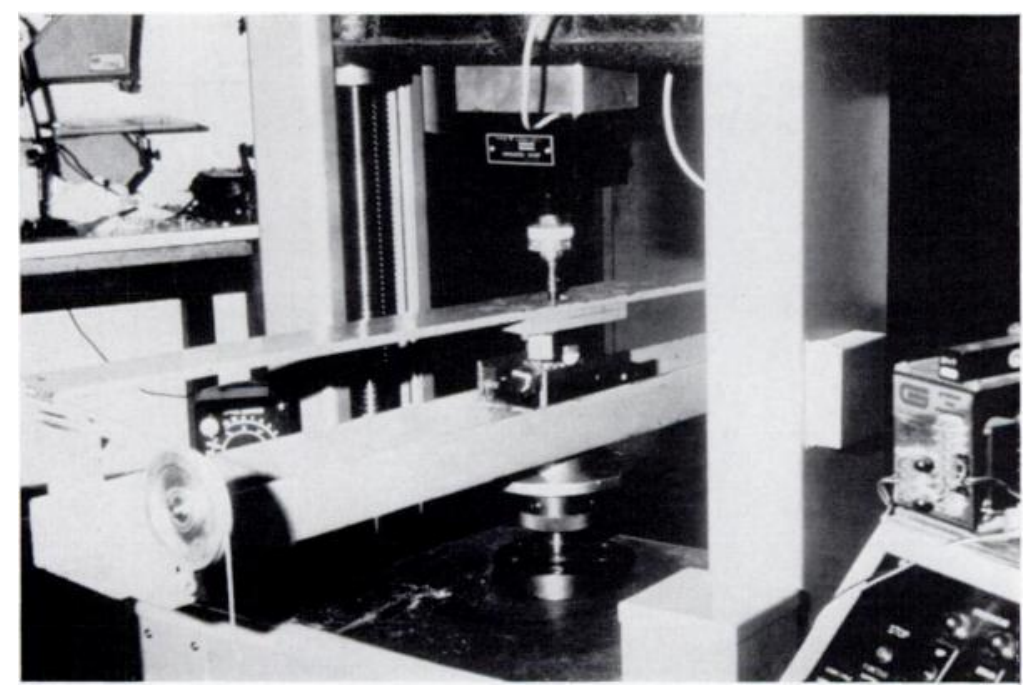

FIG. 2

The apparatus for applying twisting moments at the same time as vertical compression.

TABLE III

Initial. Looseness of the Charnley Cup at a Turning Moment of 6.8 Newton-metres ( 60 poundsforce inches)

\begin{tabular}{|c|c|c|c|}
\hline \multicolumn{3}{|c|}{ Preparation of acetabulum } & \multirow{2}{*}{$\begin{array}{l}\text { Rotation } \\
\text { (degrees) }\end{array}$} \\
\hline $\begin{array}{l}\text { Cartilage } \\
\text { reamed }\end{array}$ & $\begin{array}{c}\text { Fovea } \\
\text { cleaned }\end{array}$ & $\begin{array}{c}\text { Holes } \\
\text { drilled }\end{array}$ & \\
\hline No & No & No & $5 \cdot 7$ \\
\hline No & No & 3 & 0.4 \\
\hline No & Yes & No & $0 \cdot 8$ \\
\hline Yes & No & No & 0 \\
\hline Yes & No & 3 & 0 \\
\hline Yes & Yes & No & 0 \\
\hline Yes & Yes & Yes & 0 \\
\hline
\end{tabular}

further increase in the applied turning moment, which usually occurred at a rotation of less than 20 degrees.

In the course of the experiment one specimen was obtained from a patient whose hip had been replaced with a Charnley prosthesis and who died a week after this operation. The acetabulum was tested in the manner described above.

VOL. 54 B, NO. 4, NOVEMBER 1972 
Results-Initial looseness in relation to the condition of the acetabulum can be seen in Table III. The specimens fall clearly into two groups: those from which the cartilage had been removed, in which no looseness was detectable, and those in which the cartilage had been left intact, all of which showed significant looseness.

TABLE IV

Results of FaILURe TORQue EXPeriment Vertical load 1,960 Newtons (441 poundsforce)

\begin{tabular}{|c|c|c|c|c|c|}
\hline \multicolumn{3}{|c|}{ Preparation of acetabulum } & \multirow{2}{*}{$\begin{array}{c}\text { Type of } \\
\text { prosthetic cup }\end{array}$} & \multirow{2}{*}{$\begin{array}{c}\text { Turning moment } \\
\text { at failure } \\
\text { (Newton-metres) } \\
\text { (poundsforce-in.) }\end{array}$} & \multirow{3}{*}{ Notes } \\
\hline $\begin{array}{l}\text { Cartilage } \\
\text { reamed }\end{array}$ & $\begin{array}{c}\text { Fovea } \\
\text { cleaned }\end{array}$ & $\begin{array}{l}\text { Holes } \\
\text { drilled }\end{array}$ & & & \\
\hline No & No & No & McKee-Farrar & $36 \cdot 8 \quad(326)$ & \\
\hline No & Yes & No & $\begin{array}{l}\text { McKee-Farrar } \\
\text { Charnley } \\
\text { McKee-Farrar } \\
\text { Charnley }\end{array}$ & $\begin{array}{cc}74 & (656) \\
80 \cdot 2 & (710) \\
92 \cdot 1 & (815) \\
128 & (1,130)\end{array}$ & \\
\hline No & No & 3 & McKee-Farrar & $(920)$ & Plugs broke \\
\hline Charnley & No & No & McKee-Farrar & $139 \quad(1,235)$ & \\
\hline Gouge & Yes & No & $\begin{array}{c}\text { Charnley } \\
\text { McKee-Farrar }\end{array}$ & $\begin{array}{ll}139 & (1,235) \\
163 & (1,440)\end{array}$ & \\
\hline Charnley & Yes & No & McKee-Farrar & $156 \quad(1,385)$ & \\
\hline Gouge & Yes & 1 & $\begin{array}{c}\text { Charnley } \\
\text { McKee-Farrar }\end{array}$ & $\begin{array}{ll}110 & (970) \\
139 & (1,235)\end{array}$ & \\
\hline Charnley & No & 1 & $\begin{array}{c}\text { Charnley } \\
\text { McKee-Farrar }\end{array}$ & $\begin{array}{cr}92 \cdot 1 & (815) \\
116 & (1,025)\end{array}$ & Plug broke \\
\hline Charnley & Yes & 1 & Charnley & $128 \quad(1,130)$ & \\
\hline Charnley & No & 3 & McKee-Farrar & $188 \quad(1,660)$ & \\
\hline Gouge & Yes & 3 & McKee-Farrar & $188 \quad(1,660)$ & \\
\hline Charnley & Yes & 3 & $\overline{\text { McKee-Farrar }}$ & Over $188(1,660)$ & \\
\hline
\end{tabular}

TABLE V

Results of Failure Torque Experiment

Five cubic centimetres of blood in the acetabulum Vertical load 1,960 Newtons (441 poundsforce)

\begin{tabular}{|c|c|c|c|c|}
\hline \multicolumn{3}{|c|}{ Preparation of acetabulum } & \multirow{2}{*}{$\begin{array}{c}\text { Type of } \\
\text { prosthetic cup }\end{array}$} & \multirow{2}{*}{$\begin{array}{c}\text { Turning moment } \\
\text { at failure } \\
\text { (Newton-metres) } \\
\text { (poundsforce-in.) }\end{array}$} \\
\hline $\begin{array}{l}\text { Cartilage } \\
\text { reamed }\end{array}$ & $\begin{array}{l}\text { Fovea } \\
\text { cleaned }\end{array}$ & $\begin{array}{l}\text { Holes } \\
\text { drilled }\end{array}$ & & \\
\hline Gouge & Yes & 1 & $\begin{array}{c}\text { Charnley } \\
\text { McKee-Farrar }\end{array}$ & $\begin{array}{l}133(1,180) \\
139(1,235)\end{array}$ \\
\hline
\end{tabular}

The results of the experiment in which a turning moment was applied until failure occurred can be seen in Tables IV to VI. As would be expected, it was found that the strength of the bone-cement bond increased if the cartilage was removed. When the cartilage had been removed, however, there was little further increase in the strength of the bond if holes were drilled in the acetabulum or if the acetabular fossa was cleaned. 
The variation in strength with different compressive loads is evident from Table VI. In general the strength of the bond increased as the magnitude of the compressive load increased, but not in proportion to the load.

In all specimens loosening eventually occurred between cement and bone with fragments of bone attached to the cement, suggesting that the bone and not the cement had broken. In some specimens there were cracks in the cement and in some the cement buds in the drill holes broke. In no specimen did the cement separate from the prosthetic acetabulum.

\section{DISCUSSION}

The lowest turning moment required to twist a prosthetic socket loose in a prepared acetabulum in these tests was 44.5 Newton-metres (394 poundsforce-inches), which is more than four times larger than the highest frictional moment $(10.4$ Newton-metres or 92 poundsforce inches) recorded with serum as the lubricant, and more than twice the highest frictional moment measured even with Ringer's solution as the lubricant. It might be objected that in life the resultant force on the acetabulum is unlikely to be directed exactly along the femoral neck, and that therefore the experimental results obtained with large forces acting

TABLE VI

Rtsults of Fallure Torque Experiment at Different Vertical Loads

\begin{tabular}{|c|c|c|c|c|c|}
\hline \multicolumn{2}{|c|}{ Preparation of acetabulum } & $\begin{array}{l}\text { bulum } \\
\text { Holes } \\
\text { drilled }\end{array}$ & \multirow{2}{*}{$\begin{array}{c}\begin{array}{c}\text { Type of } \\
\text { prosthetic cup }\end{array} \\
\text { Charnley }\end{array}$} & \multirow{2}{*}{$\begin{array}{c}\begin{array}{c}\text { Vertical load } \\
\text { (Newtons) } \\
\text { (poundsforce) }\end{array} \\
0\end{array}$} & $\begin{array}{l}\text { Turning moment } \\
\text { at failure } \\
\text { (Newton-metres) } \\
\text { (poundsforce-in.) }\end{array}$ \\
\hline Charnley & Yes & 1 & & & $62.4 \quad(552)$ \\
\hline Charnley & $\begin{array}{l}\text { No } \\
\text { Yes }\end{array}$ & 1 & $\begin{array}{l}\text { Charnley } \\
\text { Charnley }\end{array}$ & $\begin{array}{l}196(44) \\
196(44)\end{array}$ & $\begin{array}{ll}44 \cdot 5 & (394) \\
68 \cdot 4 & (605)\end{array}$ \\
\hline Charnley & Yes & 1 & $\begin{array}{l}\text { Charnley } \\
\text { McKee } \\
\text { Charnley }\end{array}$ & $\begin{array}{l}1,960(441) \\
1,960(441) \\
1,960(441)\end{array}$ & $\begin{array}{cc}92 \cdot 1 & (815) \\
116 & (1,025) \\
128 & (1,130)\end{array}$ \\
\hline Charnley & Yes & 1 & $\begin{array}{l}\text { Charnley } \\
\text { Charnley }\end{array}$ & $\begin{array}{l}3,924(882) \\
3,924(882)\end{array}$ & $\begin{array}{ll}116 & (1,025) \\
128 & (1,130)\end{array}$ \\
\hline
\end{tabular}

in that direction (pressing the prosthetic acetabular cup into the bony acetabulum) give too high an estimate of the strength of the bond in life. This objection is considered not to be serious, because 1) the moments at failure were by no means proportional to the force applied in the direction of the femoral neck, and 2) even with zero force applied, the moment at failure was higher than the smallest measured in the present tests and several times higher than any frictional moment measured in a joint prosthesis.

Thus the results of these tests suggest that the frictional moment exerted on the prosthetic acetabular cup is most unlikely to approach the static failing strength of either the bond between the cup and the cement or that between the cement and the bone. Other causes of late loosening therefore remain to be sought.

If a prosthesis is securely implanted at operation, subsequent looseness in the absence of bacterial infection might be due to aseptic bone resorption or to fatigue in the materials. Fatigue or mechanical deterioration of acrylic cement is a theoretical possibility but no clinical evidence of this has so far been reported.

It was observed, as mentioned above, that in these tests failure took place in the bone rather than in the cement. Unless the fatigue strength of cement is appreciably lower, relative to its static fracture strength, than is the fatigue strength of bone relative to its static fracture

VOL. 54 B, NO. 4, NOVEMBER 1972 
strength, fatigue failure in service is to be expected in the bone and not in the cement. Nothing is known of the local stress concentrations at the cement-bone interface, but if the moments applied in service are indeed about one-quarter of the magnitude of the moments required to cause static failure, it seems possible that stresses may locally be high enough to cause fatigue fracture in the bone.

Aseptic bone resorption is another possible reason for late loosening of the acetabular cup and theoretically such aseptic resorption might be due to chemical, mechanical or thermal factors. There is no evidence that bone reacts chemically to cement.

Mechanically minute movement is likely to occur at the bone-cement interface as a response to stress, but clinical results indicate that normally this is not progressive and does not increase to the point of failure. Amstutz (1970) has further investigated this subject and believes that if "significant" initial motion is possible, loosening will occur by its progressive increase. He ascribes this partly to acrylic particles shorn from the irregular surfaces causing further bone resorption. The meaning of the word "significant" in this context is not clear, but the present findings indicate that if the acetabulum is sufficiently prepared and normal care is taken in the use of cement and the fitting of the acetabular prosthesis, initial looseness of any magnitude seems likely to be rare.

Thermal damage to tissues in direct contact with cement at the time of polymerisation is known to take place (Scales, Duff-Barclay and Burrows 1965; Charnley 1970a). Temperatures between 58 and 70 degrees Celsius have been measured between cement (Palacos) and the tissues (Ohnsorge and Goebel 1970), and irreversible protein damage is known to take place at 56 degrees Celsius (Lehnartz 1959). It therefore seems likely that the bone which is initially in immediate contact with cement is dead after implantation of the prosthesis and may therefore undergo eventual resorption. Tissue response to cement has been studied by Charnley (1970a), Charnley and Crawford (1968) and Charnley, Follacci and Hammond (1968). They showed histologically that mechanical contact between bone and cement is only temporary and that some bony resorption usually occurs. At this stage weight is transmitted mainly through a thin layer of newly formed fibrocartilage. There is some evidence that bone may later grow into this tissue leading to direct contact between newly formed living bone and cement, but this is believed to take years. There therefore seem to be grounds for believing that thermal trauma may be the major reason for bone damage at the time of implantation of the prosthesis and that this may be an important factor in the occurrence of loosening. Conceivably, loosening combined with thermal bone necrosis adjacent to cement may be important in the genesis of late, bacteriologically sterile "infections".

The present results indicate that the surgical technique used in preparing the acetabulum is not critical except that the cartilage must be removed. It is especially important to ream the cartilage close to the acetabular rim, because this area will provide the greatest resistance to torque. As cement does not bond to bone but holds by mechanical interlocking at surface irregularities, reaming of the surface is more important than a few cement projections in drill holes in different parts of the acetabulum. If the cartilage is carefully reamed away, additional holes will give only a slight increase in the torsional strength of the bond.

Obviously it is desirable to disturb the bony acetabulum as little as possible. This is especially true when protrusio acetabuli exists, with a thin acetabular floor. In three patients known to the authors, deepening of the acetabulum and the drilling of holes have probably been responsible for protrusion of the prosthesis into the true pelvis, with severe pain necessitating re-operation (Fig. 3). This phenomenon has also been reported by Welch and Charnley (1970). Thus in the light of the present findings it seems reasonable to suggest that surgical preparation of the acetabulum should be confined to the total removal of the articular cartilage and the removal of soft tissue from the acetabular fossa.

In the clinical specimen recorded in Table VII three holes had been drilled, but cartilage had been left around the rim of the acetabulum and the fovea was untouched. Under laboratory 
test conditions the long projections of cement in this specimen fractured at their bases, permitting the socket to move. The acetabular surface of the cement was smooth, indicating imperfect contact with the bone. This seems likely to be the reason for failure at an unusually low torque

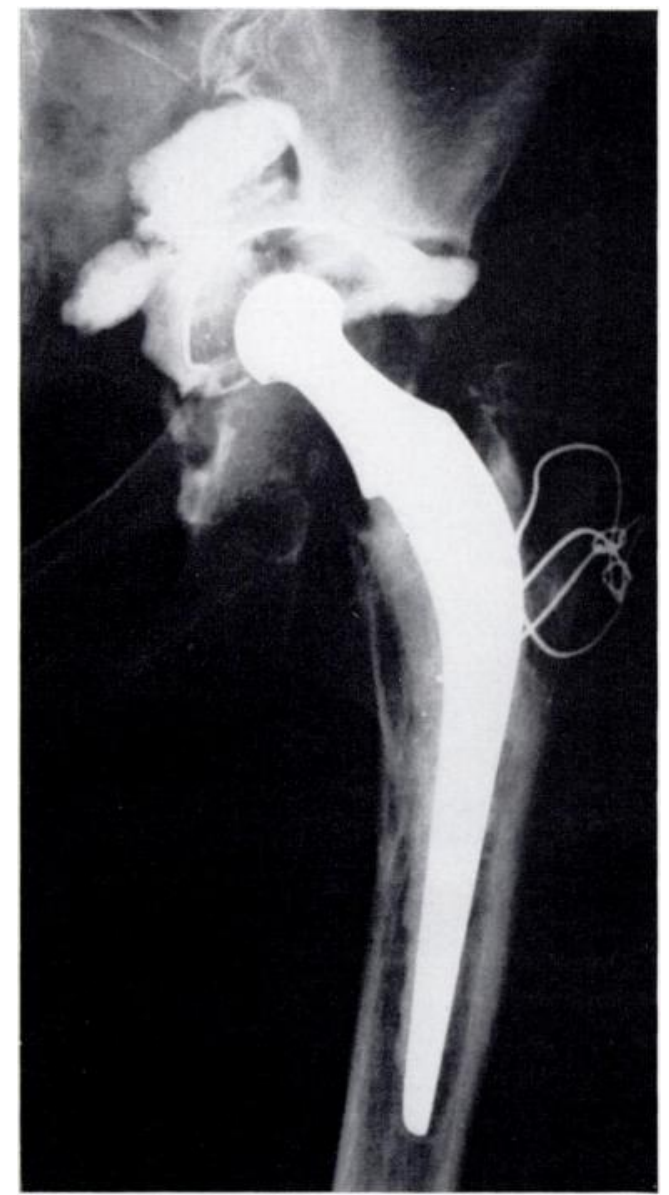

Fig. 3

Loosening of cement with protrusion of the prosthetic acetabulum.

TABLE VII

Results in Specimen from Patient Dying One Week after Operation

\begin{tabular}{|c|c|c|c|c|c|}
\hline \multicolumn{3}{|c|}{ Preparation of acetabulum } & \multirow{2}{*}{$\begin{array}{c}\text { Type of } \\
\text { prosthetic cup }\end{array}$} & \multirow{2}{*}{$\begin{array}{l}\text { Vertical load } \\
\text { (Newtons) } \\
\text { (poundsforce) }\end{array}$} & \multirow{2}{*}{$\begin{array}{l}\text { Turning moment } \\
\text { at failure } \\
\text { (Newton-metres) } \\
\text { (poundsforce-in.) }\end{array}$} \\
\hline $\begin{array}{l}\text { Cartilage } \\
\text { reamed }\end{array}$ & $\begin{array}{c}\text { Fovea } \\
\text { cleaned }\end{array}$ & $\begin{array}{l}\text { Holes } \\
\text { drilled }\end{array}$ & & & \\
\hline Charnley & No & 3 & Charnley & $1,960(441)$ & $62 \cdot 2(550)$ \\
\hline
\end{tabular}

in this specimen and the result in a specimen prepared in a similar way in the laboratory supports this conclusion (Table IV).

Since all the frictional moments so far measured in joint prostheses are appreciably lower than those which the bone-cement interface can withstand, the frictional differences between 
all-metal prostheses and those containing polyethylene might at first sight appear to be unimportant. Unless, however, it can be established that there is no possibility of late loosening being caused or assisted by fatigue failure in the bone, it seems reasonable to choose a design giving a lower rather than a higher frictional moment (in so far as the choice is based on this factor). From this point of view a polyethylene cup is to be preferred. The one McKee-Farrar prosthesis with a smaller (35-millimetre) head in which frictional moments were measured (see Table II) was of the later design, which differs from the earlier design in being arranged to transmit load through a "polar" region instead of a more nearly "equatorial" region. This feature would be expected to lead to a lower frictional moment, which is, however, still significantly larger than those measured in Charnley prostheses. The frictional moment in a metal-to-metal bearing is more sensitive to the presence or absence of fluid, and to the nature of the fluid, than in a metal-to-polyethylene bearing. Thus the possibility of an occasional large increase in frictional moments, though probably slight in either kind of prosthesis, must be considered higher in all-metal prostheses than in metal-on-polyethylene prostheses.

\section{SUMMARY}

1. Prosthetic acetabular cups of the Charnley and McKee-Farrar designs were cemented into cadaveric pelves using different procedures for preparing the acetabulum.

2. The torsional moments needed to loosen these cups were measured.

3. The torsional moments so measured were found to be from about four to more than twenty times higher than the frictional moments measured in independent tests on the two designs of prosthesis.

4. It is argued that late looseness of the acetabular component after total hip replacement, in the absence of infection, seems most likely to be due to thermal damage to the bone occurring at the time of polymerisation of the cement, and to subsequent bone resorption.

5. Surgical preparation of the acetabulum should include removal of all the articular cartilage and cleaning of the acetabular fossa, but the drilling of additional holes in the floor of the acetabulum seems unimportant.

6. The possibility of fatigue fracture in bone as a factor contributing to late loosening is an argument in favour of metal-on-polyethylene prostheses with their lower frictional moments, although the importance of this factor cannot be estimated.

Since completing this study we have had the opportunity of studying one further hip taken at necropsy from a patient who died as a consequence of a cerebrovascular accident twenty-four months after replacement of her hip by a Charnley low friction arthroplasty.

Examination of the specimen after mechanical testing showed that all the articular cartilage had been removed from the acetabulum at the time of operation. When tested mechanically this specimen failed (as had the other specimens tested in this study) at the interface between the "cement" and the bony pelvis. The turning moment at failure was 117 Newton-metres (1,030 poundsforce-inches).

The turning moment at failure in this prosthesis fell within the range of those observed in our post-mortem study. Thus the values obtained in our post-mortem experiments are representative of those which can be obtained at operation in life.

The findings in this hip reinforce the conclusion that the essential operative step in the preparation of the acetabulum is the complete removal of all cartilage.

\section{REFERENCES}

Amstutz, H. C. (1970): Complications of Total Hip Replacement. Clinical Orthopaedics and Related Research, $72,123$.

Chapchal, G., and Müller, W. (1970): Total Hip Replacement with the McKee Prosthesis. A Study of 121

Follow-up Cases Using Neutral Cement. Clinical Orthopaedics and Related Research, 72, 115.

Charnley, J. (1970a): Acrylic Cement in Orthopaedic Surgery. Edinburgh and London: E. \& S. Livingstone.

Charnley, J. (1970b): Total Hip Replacement by Low-Friction Arthroplasty. Clinical Orthopaedics and Related Research, 72, 7.

Charnley, J., and Crawford, W. J. (1968): Histology of Bone in Contact with Self-curing Acrylic Cement. Journal of Bone and Joint Surgery, 50-B, 228. 
Charnley, J., Follacci, F. M., and Hammond, B. T. (1968): The Long-term Reaction of Bone to Self-curing Acrylic Cement. Journal of Bone and Joint Surgery, 50-B, 822.

Charnley, J., and Kettlewell, J. (1965): The Elimination of Slip between Prosthesis and Femur. Journal of Bone and Joint Surgery, 47-B, 56.

Freeman, P. A. (1970): McKee-Farrar Total Replacement of the Hip Joint in Rheumatoid Arthritis and Allied Conditions. Clinical Orthopaedics and Related Research, 72, 106.

Hughes, J., Paul, J. P. P., and Kenedi, R. M. (1970): Control and Movement of the Lower Limbs, p. 147. In Modern Trends in Biomechanics-1. Edited by D. C. Simpson. London: Butterworths.

LANGenskiöld, A., and Salenius, P. (1970): Total Replacement of the Hip by the McKee-Farrar Prosthesis. Clinical Orthopaedics and Related Research, 72, 104.

Lehnartz, E. (1959): Einführung Indie chemische Physiologie. 8te Auflage. Berlin: Springer Verlag.

McKeE, G. K. (1970): Development of Total Prosthetic Replacement of the Hip. Clinical Orthopaedics and Related Research, 72, 85.

Morris, J. B., and Nicholson, O. R. (1970): Total Prosthetic Replacement of the Hip Joint in Auckland. Clinical Orthopaedics and Related Research, 72, 33.

OHNSORGE, J., and Goebel, G. (1970): Die Verwendung unterkühlter Metallendoprothesen in der Hüftchirurgie. Zeitschrift für Orthopädie und ihre Grenzgebiete, 107, 683.

Paul, J. P. (1967): Forces Transmitted by Joints in the Human Body. Proceedings of the Institution of Mechanical Engineers, 181 (3J), 8.

Postel, M., and Kerboull, M. (1970): Total Prosthetic Replacement in Rapidly Destructive Arthrosis of the Hip Joint. Clinical Orthopaedics and Related Research, 72, 138.

Rydell, N. W. (1966): Forces Acting on the Femoral Head-Prosthesis. Acta orthopaedica Scandinavica, Supplementum 88.

Scales, J. T., Duff-Barclay, I., and Burrows, H. J. (1965): Some Engineering and Medical Problems associated with Massive Bone Replacement. In Biomechanics and Related Bio-Engineering Topics (Ed. Kenedi). Oxford: Pergamon.

Weber, B. G. (1970): Total Hip Replacement with Rotation-Endoprosthesis (Trunnion-bearing Prosthesis). Clinical Orthopaedics and Related Research, 72, 79.

Welch, R. B., and Charnley, J. (1970): Low-Friction Arthroplasty of the Hip in Rheumatoid Arthritis and Ankylosing Spondylitis. Clinical Orthopaedics and Related Research, 72, 22.

Wilson, J. N., and Scales, J. T. (1970): Loosening of Total Hip Replacements with Cement Fixation. Clinical Orthopaedics and Related Research, 72, 145.

VOL. 54 B, NO. 4, NOVEMBER 1972

C 